\title{
An Efficient Procedure for DNA Isolation and Profiling of the Hyper Variable MtDNA Sequences
}

\author{
Nazia Akbar ${ }^{1}$, Habib Ahmad ${ }^{1}$, Muhammad Shahid Nadeem ${ }^{1}$, Nasir Ali $^{1}$ and Muhammad Saadiq ${ }^{2}$ \\ 1. Department of Genetics, Hazara University, Garden Campus, Mansehra 21300, Pakistan \\ 2. Department of Chemistry, Bacha Khan University, Charsadda, Khyber Pakhtunkhwa, Pakistan
}

\begin{abstract}
Present study describes the results of an efficient protocol for the isolation of good quality DNA from human saliva. The protocol includes collection of saliva in sterile specimen tubes, followed by the cell lysis. After formation of cell lysate, proteins wereextracted by phenol chloroform treatment for purification of DNA. The purified DNA was precipitated by adding equal volume of isopropanol to the treated supernatant. After isolation DNA pellet was washed with $70 \%$ ethanol, air-dried and was suspended in $30 \mu \mathrm{L}$ of double distilled water. Best quality of DNA was extracted from the saliva samples and the PCR product was amplified for hyper-variable regions (HV1\& HV2) of the mitochondrial DNA. The genes were cleaned with GeneAll gel elution kit (Gel SV) (Cat. No. 102-10) and sequenced accordingly. The DNA isolation protocol presented here is recommended for the isolation, best quality and yield of DNA from the human saliva.
\end{abstract}

Key words: Human saliva, DNA isolation, $m t$ DNA sequences, forensic study.

\section{Introduction}

This paper describes a cost-effective and reliable protocol for isolating high quality DNA from the saliva samples for larger population studies of molecular anthropology, pathology, forensics and epidemiology. However, the DNA isolation kits are commercially available but are generally not at affordable prices especially in the developing countries. On the other hand it is very difficult to obtain blood samples from volunteers $[1,2]$, for molecular study of larger populations. Therefore, it is imperative to develop an efficient protocol for the isolation of quality DNA from human saliva. Our experience shows that DNA isolation from buccal cells was easier and safe as compared to the collection blood samples [2]. The improved methods for mitochondrial DNA ( $m t$ DNA) analysis in forensics, which were started in the early 1990 s, have led to the present day $m t$ DNA testing in public and private laboratories. Forensic analysis

Corresponding author: Habib Ahmad, Ph.D., professor, research field: genetics. E-mail: drhahmad@gmail.com and naziasaadiq@gmail.com. usually involves examination of the sequence variation within hypervariable (HV) regions, HV1 and HV2. The laboratories generally work with faintly different ranges, HV1 spans at least from position $\sim 16,024$ to $\sim 16,365$ and HV2 from position $\sim 73$ to $\sim 340$. The practices of performing forensic $m t$ DNA sequence analysis have changed extremely little over the past twenty years. Alternative approaches have been projected and developed, and new technologies have emerged, but the core methods have barely changed [3].

Review of the available information shows that saliva is an excellent source of DNA because the buccal cells available in it are constantly released from the cheek and can be obtained at any time. Furthermore its sample collection is easy, quick and non-invasive [4] and have been recommended as an alternate source for DNA isolation for clinical and research purposes [5]. Buccal cells can be obtained for DNA isolation through mouthwashes, cytobrushes, swabs, treated cards and whole saliva collection but studies have concluded that cytobrush appears to be the most appropriate method with good quality and 
high security in multicentre studies [6]. As our research study was planned for elaborating molecular anthropology of 1,000 s of people of different tribes, which was only possible through establishing our own sampling and DNA profiling procedures, which are presented here as a reference for use of variety of interest groups dealing with biodiversity of human race at DNA level.

\section{Materials and Methods}

Saliva samples were collected from volunteers of 18-25 years of the Districts Abbottabad and Mansehra, Pakistan. Proper instructions were provided to the volunteers for vigorously rinsing mouth for one and a half minutes, and brushing teeth thereafter. Each subject was given $3-5 / \mathrm{mL}$ of $5 \%$ sucrose solution for rinsing mouth for two to three minutes and then spit into $15 / \mathrm{mL}$ sterile specimen tube, the swab thus obtained were stored at $-20{ }^{\circ} \mathrm{C}$ till processing with our modified protocol of Ralser [7]. DNA was isolated by taking $1.00 / \mathrm{mL}$ of liquid salivain $1.5 / \mathrm{mL}$ eppendorf tube. $100 \mu \mathrm{L}$ of lysis solution $(2 / \mathrm{mL}$ lysis buffer +10 $\mu \mathrm{L}$ of Proteinase $\mathrm{K}+3 \mu \mathrm{L}$ of marcaptoethanol) was added to saliva sample and was mixed well. Sample was then incubated at $56{ }^{\circ} \mathrm{C}$ for $1: 30 \mathrm{~min}$. After incubation $600 \mu \mathrm{L}$ of Phenol:Chloroform (1:1) solution was added and was incubated at once for 5 min at room temperature. Sample was then centrifuged at 10,000 rpm for $10 \mathrm{~min}$ and supernatant was transferred into a fresh tube very carefully. Equal volume of isopropanol was added to the subjected supernatant and was incubated at $20{ }^{\circ} \mathrm{C}$ for $20 \mathrm{~min}$. Sample was centrifuged again at $10,000 \mathrm{rpm}$ for 15 min and upper layer was discarded and pellet was washed with $70 \%$ ethanol. Ethanol was discarded after centrifugation at $8,000 \mathrm{rpm}$ for $5 \mathrm{~min}$ and pellet was air-dried. Thirty micro litre of double distilled water was added to the dried DNA pellet and was incubated at $56{ }^{\circ} \mathrm{C}$ for $10 \mathrm{~min}$. DNA quality and quantity was then measured with Agarose gel electrophoresis.

\subsection{Gel Electrophoresis of DNA Samples}

One $g$ of agarose in 100/mL of TAE-buffer ( $1 \%$ gel) was heated in a microwave oven for one minutes. The solution was cooled to $45^{\circ} \mathrm{C}$ and $10 \mu \mathrm{L}$ of ethidium bromide was added. The gel solution was loaded onto a gel caster, kept at room temperature until solidified. The comb was removed and the gel was placed in an electrophoresis apparatus containing 200/mL of TAE-buffer. Five $\mu \mathrm{L}$ of DNA sample, mixed with $3 \mu \mathrm{L}$ DNA loading dye was applied to the agarose gel. The electrophoresis process was carried out at 80 volts for $10 \mathrm{~min}$ and then 100 volts until the dye front was $2-3 \mathrm{~cm}$ from the gel bottom. The presence and position of DNA bands was visualized and photographed, its report is provided in Fig. 1.

\subsection{Amplification of DNA Fragments}

PCR was performed for the amplification of HVSI and HVSII regions of the $m t \mathrm{DNA}$ of selected ethnic groups. A typical PCR mix contained $200 \mu \mathrm{M}$ of dNTPs, $25 \mathrm{mM}$ of $\mathrm{MgCl}$, 10x Taq Buffer, 20 Pmol of forward and reverse primers each, 50ng of template DNA, $0.5 \mu \mathrm{L}$ (2.5 U) of Taq DNA Polymerase; made the final volume of $25 \mu \mathrm{L} \mathrm{dH} 2 \mathrm{O}$. The conditions for amplification of the said genes in thermal cycler

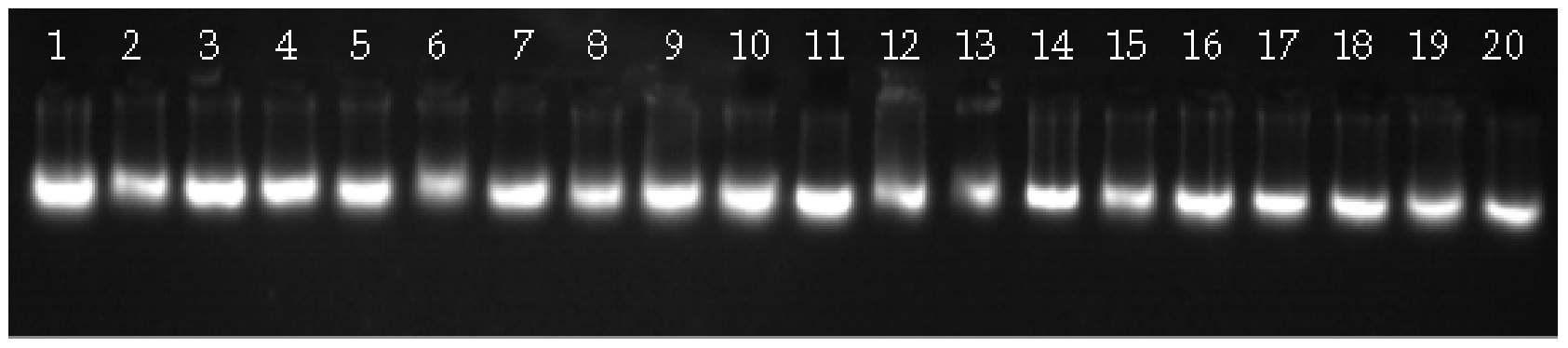

Fig. 1 Gel documentation image of genomic DNA extracted from Human saliva. 
(Applied Biosystems-2720) were adjusted at $95{ }^{\circ} \mathrm{C}$ for $4 \mathrm{~min}$ as pre PCR denaturation step, 35 repeated cycles of denaturation for $40 \mathrm{~s}$, annealing was $55^{\circ} \mathrm{C}$ for $1 \mathrm{~min}$, extension at $72{ }^{\circ} \mathrm{C}$ for $1 \mathrm{~min}$. A final extension step was carried out at $72{ }^{\circ} \mathrm{C}$ for $5 \mathrm{~min}$. The PCR products of all the samples were resolved on $1 \%$ agarose gel in gel electrophoresis (Figs. 2-3).

\subsection{Elution of PCR Product}

Gel containing PCR products was excised with the help of sterile blades and kept in labelled Eppendorf tubes at $-20{ }^{\circ} \mathrm{C}$. Following procedure was adopted from GeneAll Gel Elution Kit (SV) Cat. No. 102-101 to isolate the product from the gel.

$500 \mu \mathrm{L}$ of GB solution were added into the tube containing gel fragment of amplified HVS regions by PCR and were incubated at $60^{\circ} \mathrm{C}$ for 10 min until the gel was properly dissolved. The dissolved solution was shifted to VS column, was centrifuge at $13,000 \mathrm{rpm} / 1 \mathrm{~min}$ and liquid from the sink tube was discarded. After that $500 \mu \mathrm{L}$ of wash buffer was added to the column and was centrifuged at 13,000 for $2 \mathrm{~min}$. Liquid in the sink tube was removed and the VS column was centrifuged again for 2 mints to complete washing of PCR product. At the end the column was shifted to a fresh eppendorf tube and $50 \mu \mathrm{L}$ of water was added and was incubated at $60{ }^{\circ} \mathrm{C}$ for $2 \mathrm{~min}$ and were then kept at room temperature for $5 \mathrm{~min}$ and finally was centrifuged at $13,000 \mathrm{rpm}$ for $2 \mathrm{~min}$. The isolated PCR product was then checked on agarose gel electrophoresis (Figs. 4A and 4B). The purified PCR product was sent to Macrogen Inc. Korea for sequence analysis. Sequencing was performed using the Big Dye Terminator Cycle Sequencing Kit (AB) and sequences were analyzed on a 3730 Genetic Analyzer (AB).

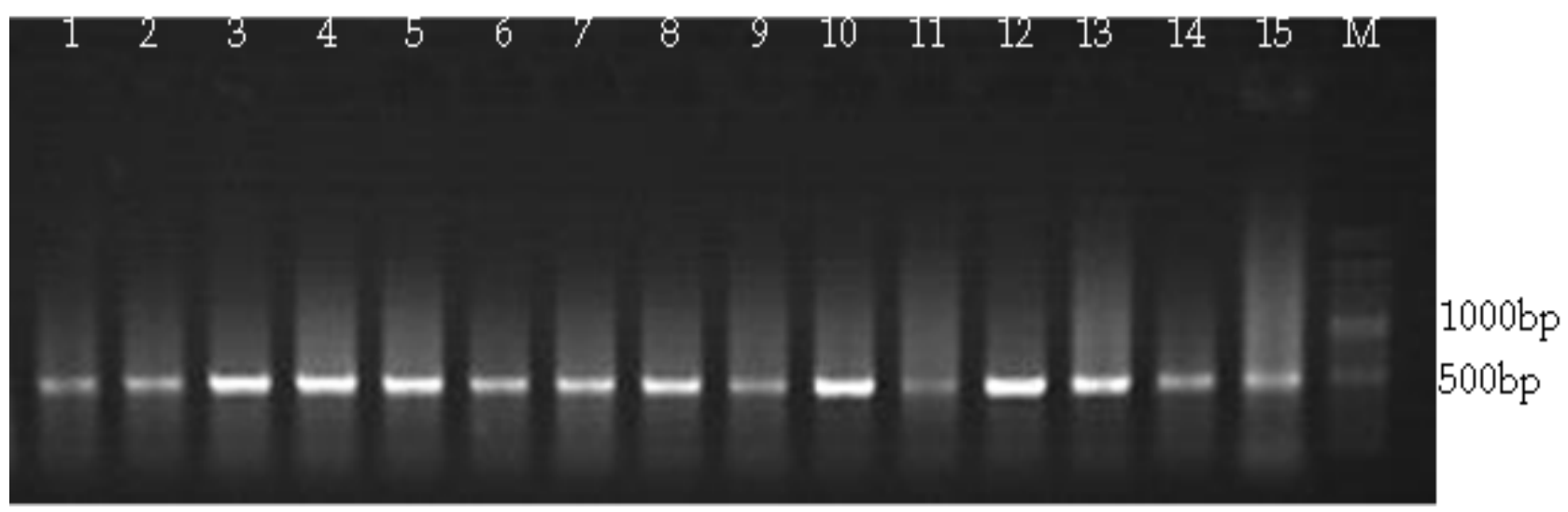

Fig. 2 Agarose gel electrophoresis photograph of amplified $m t$ DNA HVSI region.

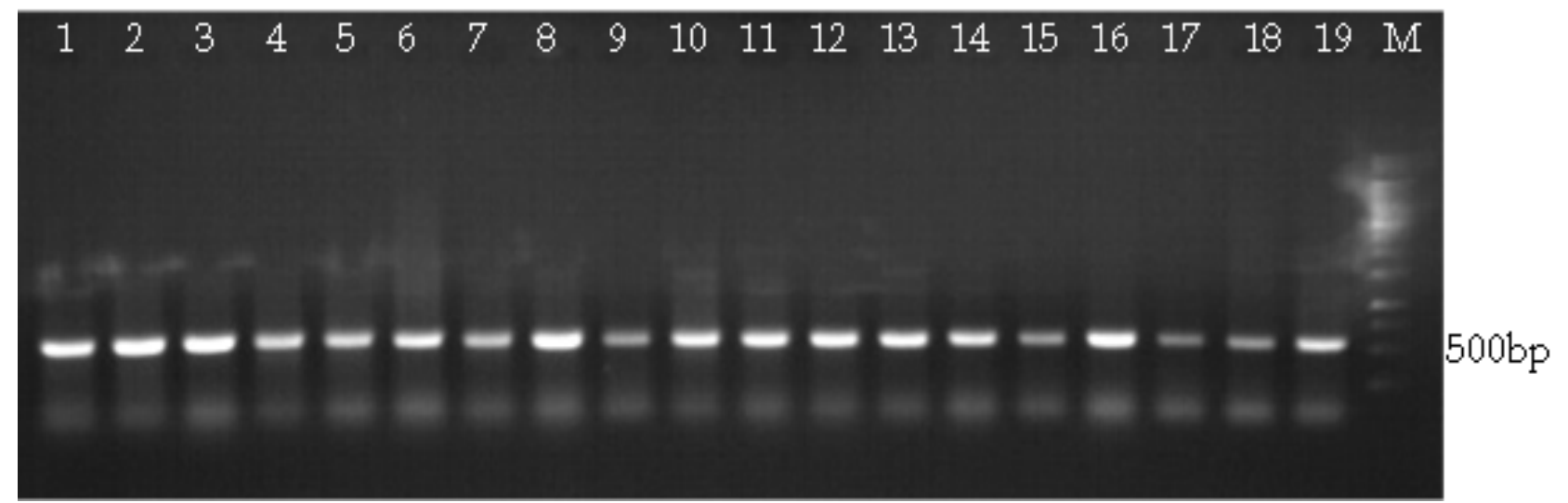

Fig. 3 Agarose gel electrophoresis photograph of amplified $m t$ DNA HVSII region. 

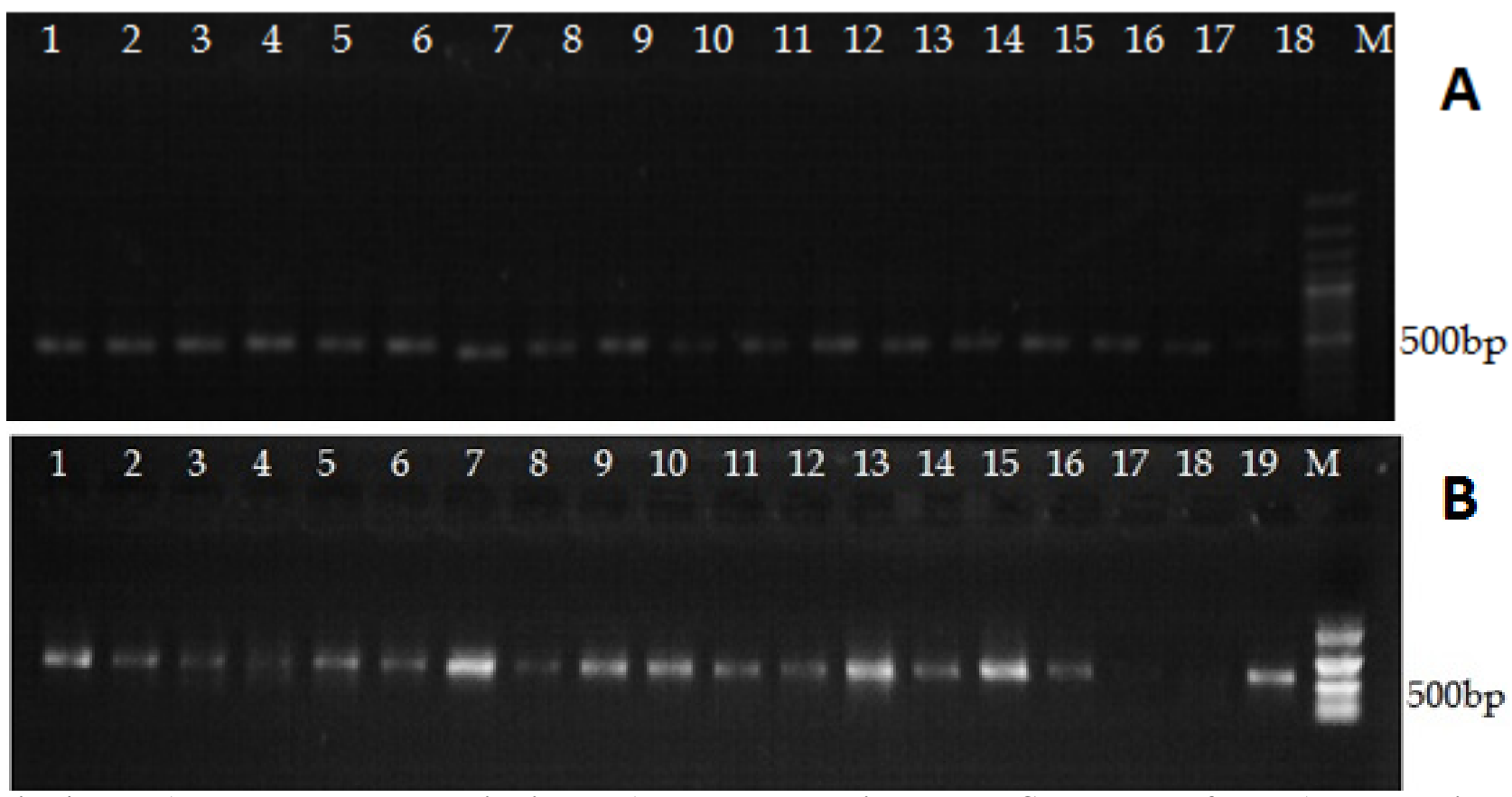

Fig. 4 The Agarose gel electrophoresis pictures A and B representing eluted PCR products of mtDNA hyper variable sequences I and II respectively.

\section{Results and Discussion}

Our experience of DNA extraction from human saliva through the modified protocol of Ralser [7] and its PCR product as given in Figs. 2 \& 3 shows this protocol is excellent for quality DNA extraction from human saliva throughout the year. No degradation of DNA was observed in the samples. It is evident from the figure 1 that all the samples had approximately similar amount of best quality DNA. In this protocol no sophisticated equipment, no high grade chemicals, no RNase treatment even during experiment was used. For incubation, common gas heater and steel pot were also used because of less availability of electricity. By using the above protocol, we were able to extract high quality genomic DNA (Fig. 1) suitable for PCR reaction and downstream applications. Furthermore to counter check the quality of the extracted DNA, the PCR amplified products were eluted (Fig. 4) and sequenced. The sequence data showed that the amplified fragments were indeed HVS regions of $m t$ DNA. The sequence data obtained was BLAST against the entire available nucleotide database using online tool at NCBI (http://blast.ncbi.nlm.nih.gov/
Blast.cgi). The protocol developed in this study can act as a useful tool for forensic and epidemiological studies. It is economical, less time consuming and handy in application.

Through this protocol, DNA is extracted throughout the year, from different ethnic groups of districts Abbottabad and Mansehra, no sophisticated equipment, no high-grade chemicals, no RNAs were used. The extracted DNA are intact, have high quantity, quality and highly suitable for many molecular biological applications such as PCR, nucleotides sequencingetc. The major drawback of utilizing commercial kits for DNA extraction in teaching labs is that they are highly expensive and secondly the students cannot be properly trained and educated. Blood is currently the most commonly used source of DNA for genetic testing. The disadvantages of using blood include invasive collection, need for a trained phlebotomist, special storage, and time consuming DNA extraction [8].

\section{Conclusions}

Saliva is an attractive alternate for DNA isolation as it gives the same results as DNA from blood and may 
be collected non-invasively from the inside of the cheek easily $[9,10]$. In past scientists has focused only on the adequacy of DNA yields from buccal (cheek) cell and oral-rinse (mouthwash) samples for basic polymerase chain reaction (PCR) protocols and genotyping [11-14]. To overcome on the above hindrance and resolve this issue, the protocol developed in this study can act as useful tools for molecular biologists working on ethnicity and forensics investigation. The DNA extracted using our protocol is suitable for PCR and other downstream applications in molecular biology.

\section{Acknowledgments}

This paper is a part of the $\mathrm{PhD}$ work of the principal author. We are grateful to Higher Education Commission, Pakistan for proving funds to conduct this research. All the member of Human Genetics Lab, Department of Genetics, Hazara University is acknowledged for their contribution towards finalizing this study.

\section{References}

[1] Le, M. L., Lum, J. A., Saltzman, B., Visaya, V., Nomura, A. M., and Kolonel, L. N. 2001. "Feasibility of Collecting Buccal Cell DNA by Mail in a Cohort Study." Cancer Epidemiology, Biomarkers \& Prevention 10: 701-3.

[2] Hansen, T. V., Simonsen, M. K., Nielsen, F. C., and Hundrup, Y. A. 2007. "Collection of Blood, Saliva, and Buccal Cell Samples in a Pilot Study on the Danish Nurse Cohort: Comparison of the Response Rate and Quality of Genomic DNA." Cancer Epidemiology, Biomarkers \& Prevention 16: 2072-6.

[3] Melton, T., Holland, C., and Holland, M. 2012. "Forensic Mitochondrial DNA Analysis: Current Practice and Future Potential." Forensic Science Review 24: 101.

[4] Van-Wieren-de-Wijer, D. B., Maitland-van-der-Zee, A. H., andde Boer, A., et al. 2009. "Determinants of DNA Yield and Purity Collected with Buccal Cell Samples." European Journal of Epidemiology 24: 677-82.

[5] Heath, E. M., Morken, N. W., Campbell, K. A., Tkach,
D., Boyd, E. A., and Strom, D. A. 2001. "Use of Buccal Cells Collected in Mouthwash as a Source of DNA for Clinical Testing." Archives of Pathology \& Laboratory Medicine 125: 127-33.

[6] Mulot, C., Stücker, I., Clavel, J., Beaune, P., and Loriot, M. A. 2005. "Collection of Human Genomic DNA from Buccal Cells for Genetics Studies: Comparison between Cytobrush, Mouthwash, and Treated Card." Journal of Biomedicine and Biotechnology: 291-6.

[7] Ralser, M., Querfurth, R., Warnatz, H. J., Lehrach, H., Yaspo, M. L., and Krobitsch, S. 2006. "An Efficient and Economic Enhancer Mix for PCR.” Biochemical and Biophysical Research Communications 347 (3): 747-51.

[8] Thomson, D. M., Brown, N. N., and Clague, A. E. 1992. "Routine Use of Hair Root or Buccal Swab Specimens for PCR Analysis: Advantages over Using Blood." Clinica Chimica Acta 207: 169-74.

[9] Elit, L., Jack, E., Kwan, E., Baigal, G., and Narod, S. 2001. "A Unique BRCA1 Mutation Identified in Mongolia." International Journal of Gynecological Cancer 11: 241-3.

[10] Rylander-Rudqvist, T., et al. 2006. "Quality and Quantity of Saliva DNA Obtained from the Self-administrated Oragene Method-A Pilot Study on the Cohort of Swedish Men." Cancer Epidemiology, Biomarkers \& Prevention 15 (9): 1742-5.

[11] Cozier. Y. C., Palmer, J. R., and Rosenberg, L. 2004. "Comparison of Methods for Collection of DNA Samples by Mail in the Black Women's Health Study." Annals of Epidemiology 14: 117-22.

[12] Garcia-Closas, M., Egan, K. M., Abruzzo, J., Newcomb, P. A., Titus, E. L., Franklin, T., Bender, P. K., Beck, J. C., Le, M. L., Lum, A., Alavanja, M., Hayes, R. B., Rutter, J., Buetow, K., Brinton, L. A., and Rothman, N. 2001. "Collection of Genomic DNA from Adults in Pidemiological Studies by Buccal Cytobrush and Mouthwash." Cancer Epidemiology, Biomarkers \& Prevention 10: 687-96.

[13] Kozlowski, L. T., Vogler, G. P., Vandenbergh, D. J., Strasser, A. A., O'Connor, R. J., and Yost, B. A. 2002. "Using a Telephone Survey to Acquire Genetic and Behavioral Data Related to Cigarette Smoking in "Made-anonymous" and "Registry" Samples." American Journal of Epidemiology 156: 68-77.

[14] Lench, N., Stanier, P., and Williamson, R. 1988. "Simple Non-invasive Method to Obtain DNA for Gene Analysis." Lancet 1: 1356-8. 